\title{
OCHRONA ŚRODOWISKA W GMINACH O SZCZEGÓLNYCH WALORACH PRZYRODNICZYCH PRZYKLAD GMIN POWIATU WIELUŃSKIEGO POSIADAJĄCYCH PARK KRAJOBRAZOWY
}

\author{
ENVIRONMENTAL PROTECTION IN COMMUNES \\ OF SPECIFIC NATURAL VALUES \\ THE EXAMPLE OF THE WIELUŃSKI COUNTY COMMUNES OWING A \\ LANDSCAPE PARK
}

\begin{abstract}
In the dynamic social-economic processes the environmental protection of the areas of great natural interest is a challenge for territorial units (communes). The multiplicity and diversity of natural environment and cultural territory is a specific endogenous resource, which is a value but it requires the intensification of the activities for the sake of their protection.

The subject of the article is the issue of environmental protection, the subject of the research are Wieluński County communes which have outstanding natural values that are a tourist attraction for the inhabitants of łodzkie, śląskie and opolskie voivodeship. In the article, the main fields of local government activity in the scope of environmental protection are presented and the identification of the main problems has been carried out. A particular attention was paid to the communities which have a landscape park within their area.
\end{abstract}

Key words: community, natural values, landscape park, environmental protection

JEL Calassification: Q58, Q56

\section{Wstęp}

W naukach ekonomicznych zasoby oraz walory środowiska przyrodniczego interpretowane są jako kapitał przyrodniczy, który wraz z kapitałem ekonomicznym i ludzkim współtworzy warunki dla rozwoju społeczno-gospodarczego.

* Dr, Uniwersytet Łódzki, Wydział Ekonomiczno-Socjologiczny, Instytut Gospodarki Przestrzennej, Katedra Gospodarki Regionalnej i Środowiska. 
Paradygmat trwałego i zrównoważonego rozwoju znacznie wzmocnił rangę kapitału przyrodniczego podkreślając jego niezbędność w procesach rozwoju. Podejście to znalazło uzasadnienie w badaniach nad usługami ekosystemów (usługi z natury, usługi z przyrody), które identyfikują wszelkie „korzyści”, jakie czerpie człowiek ze środowiska przyrodniczego w postaci dóbr i usług, a które są mu niezbędne do zaspokojenia potrzeb biologicznych, społecznych i gospodarczych ${ }^{1}$.

W ostatnich latach mówi się o terytorializacji polityki rozwoju (place based policy), jako nowej koncepcji (idei) planowania rozwoju na poziomie lokalnym jak i regionalnym ${ }^{2}$. Koncepcja ta wyraźnie podkreśla rolę terytorium w procesach rozwoju i eksponuje znaczenie jego unikatowych cech (relacji, doświadczeń, tożsamości) czy zasobów materialnych i niematerialnych ${ }^{3}$. Podejście to kładzie nacisk na efektywne i innowacyjne wykorzystanie zasobów endogenicznych. Zasoby przyrodnicze tj. dane przez naturę dobra materialne i niematerialne oraz związane z nimi użyteczności, zlokalizowane w konkretnej przestrzeni, tworzą kapitał tych miejsc (kapitał terytorialny) ${ }^{4}$. Ich występowanie w określonej przestrzeni (terytorium) świadczy o predyspozycji i możliwości gospodarczego wykorzystania, bowiem „,zasoby nie są, ale stają się”. Dokonując waloryzacji dóbr przyrodniczych wskazujemy na ich przydatność (użyteczność) ze względu na określony cel zastosowania oraz zakres wykorzystania. $Z$ perspektywy władz lokalnych istotne jest zatem zdefiniowanie kapitału terytorialnego, a następnie zaprojektowanie polityki rozwoju pozwalające na wydobycie indywidualnych i niepowtarzalnych cech danego terytorium. Możemy zatem mówić o specjalizacji w kontekście wyboru ścieżki rozwojus.

${ }^{1}$ R. Costanza et al., The value of the world's ecosystem services and natural capital, Nature 1997 w 387(6630).

${ }^{2}$ F. Barca, An Agenda for a Reformed Cohesion Policy. A place-based approach to meeting European Union challenges and expectations, Independent Report prepared at the request of Danuta Hübner, Commissioner for Regional Policy, 2009, http://ec.europa.eu/regional_policy/archive/policy/ future/pdf/report_barca_v0306.pdf, (dostęp: 28.01.2016).

${ }^{3}$ Szerzej o terytorium i jego znaczeniu w procesach rozwoju pisze: A. Jewtuchowicz, Terytorium $i$ wspótczesne dylematy jego rozwoju, Wydawnictwo Uniwersytetu Łódzkiego, Łódź 2005; I. Pietrzyk, Polityka regionalna Unii Europejskiej i regiony w państwach członkowskich, PWN, Warszawa 2000.

${ }^{4}$ Pojęcie kapitału terytorialnego jest nowym pojęciem rozwijanym na gruncie polityki regionalnej. Szerzej: R. Camagni, R. Capello (2009), Knowledge-based Economy and Knowledge Creation: The Role of Space, [w:] Fratesi U., Senn L. (eds.), Growth and Competitiveness in Innovative Regions: Balancing Internal and External Connections, Springer Verlag, Berlin, pp. 145-166; R. Camagni, Towards a Conclusion: Regional and Territorial Policy Recommendations, [w:] R. Capello, R. Camagni, U. Fratesi, R. Chizzolini (2008), Modelling Regional Scenarios for the Enlarged Europe, Springer Verlag, Berlin, 283-306.

${ }^{5}$ R. CapelloAuthor Vitae, A. CaragliuAuthor Vitae, U. Fratesi, Global trends and the economic crisis: Future alternative European growth strategies, [w:] Technological Forecasting and Social 
Występowanie w przestrzeni lokalnej cennych, unikatowych walorów przyrodniczych stanowi atuty rozwoju i podkreśla jej charakter, ale wiążę się również z określonym działaniem w kontekście ochrony. Ochrona przyrody jako całości, a w szczególności ochrona konkretnej przestrzeni cennej przyrodniczo, w warunkach dynamicznych procesów społeczno-gospodarczych, jest wyzwaniem dla jednostek terytorialnych. Oznacza bowiem „organizację terytorium”, której nadrzędnym celem nie są wyłącznie doraźne korzyści gospodarcze czy społeczne, ale trudno mierzalne, oddalone w czasie zyski ekologiczne. W tym kontekście ustanawianie prawnych form ochrony przyrody jest niejako innowacyjną drogą rozwoju terytorium, pożądaną, aczkolwiek niejednokrotnie trudną i nie zawsze akceptowaną. Najbardziej newralgiczną kwestią jest ochrona i racjonalne wykorzystanie przestrzeni (krajobrazu) oraz minimalizacja, likwidacja czy neutralizacja negatywnych skutków oddziaływania lokalnej społeczności na środowisko.

Celem artykułu jest zatem identyfikacja głównych obszarów aktywności władz lokalnych gmin powiatu wieluńskiego w zakresie ochrony środowiska ze szczególnym uwzględnieniem gmin na terenie, których znajduje się park krajobrazowy. Dla realizacji powyższego celu wykorzystano zasoby Banku Danych Lokalnych GUS oraz materiały źródłowe pozyskane z urzędów gmin $^{6}$.

\section{Obszar badań}

Powiat wieluński jest jednym z 24 powiatów województwa łódzkiego, położonym w jego południowo-zachodniej części (rys. 1). Powierzchnia powiatu wynosi $926,48 \mathrm{~km}^{2}$, stanowiąc $5,1 \%$ obszaru województwa łódzkiego. Strukturę administracyjną tworzy 10 gmin, w tym 9 gmin wiejskich $(58,1 \%$ ludności) i 1 gmina miejsko-wiejska (41,9\% ludności). Najmniejszą gminą pod względem zajmowanej powierzchni jest Skomlin $\left(55,2 \mathrm{~km}^{2}\right)$, największą zaś Wieluń $\left(130,6 \mathrm{~km}^{2}\right)$. Liczba sołeckich osad wiejskich wynosi 143 i jest zbliżona do średniej w województwie.

Change, Volume 98, September 2015, s. 120-136, http://www.sciencedirect.com/science/article/pii/ S0040162515001717 (dostęp: 01.02.2016).

${ }^{6} \mathrm{~W}$ artykule wykorzystano materiały przygotowane przez autora na potrzeby Zintegrowanej Strategii Rozwoju Powiatu Wieluńskiego na lata 2014-2020, Uchwała Nr XL/269/13 Rady Powiatu w Wieluniu z dnia 30 grudnia 2013 r., zespół ekspertów naukowych A. Nowakowska (kierownik), E. Boryczka, M. Feltynowski, Z. Przygodzki, A. Rzeńca, M.E. Sokołowicz. 


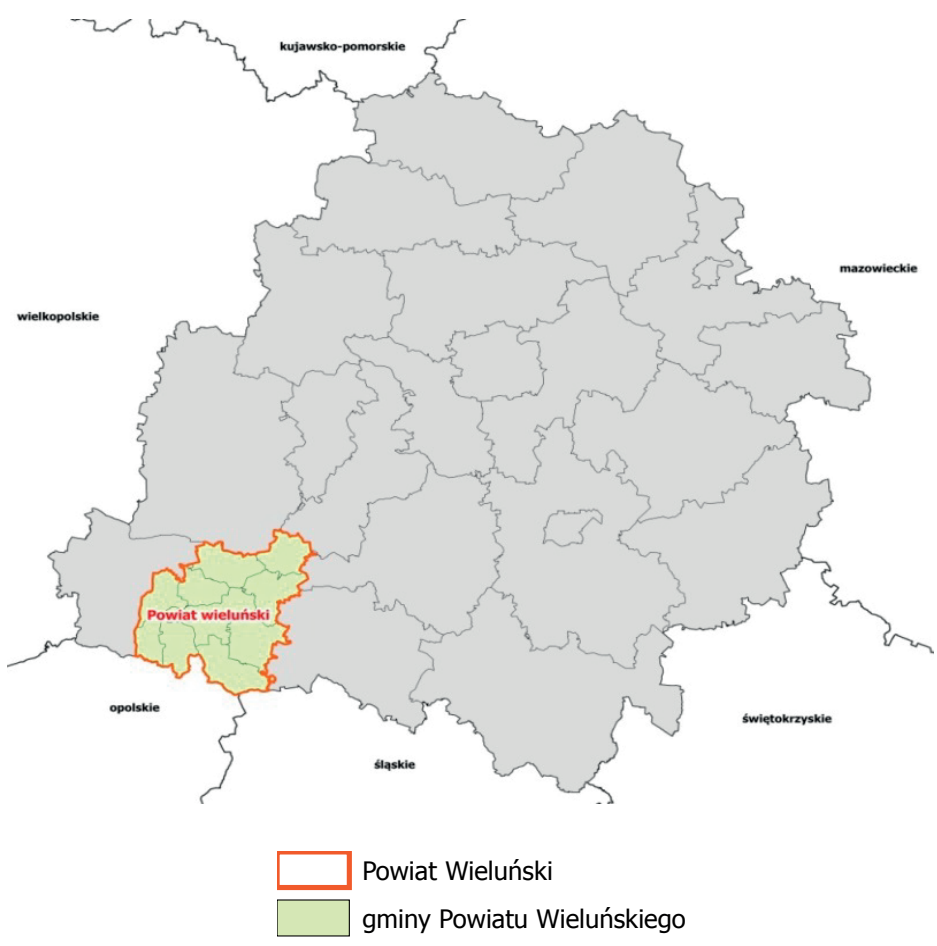

Rysunek 1. Położenie powiatu wieluńskiego na tle podziału administracyjnego województwa lódzkiego

Źródto: opracowanie własne.

Wysokie walory przyrodnicze oraz kulturowe powiatu przesądziły o utworzeniu na jego terenie dwóch parków krajobrazowych: Załęczańskiego Parku Krajobrazowego oraz Parku Krajobrazowego Międzyrzecza Warty i Widawki. W przypadku 3 gmin tj. Konopnicy, Pątnowa i Wierzchlasu park krajobrazowy zajmuje znaczną część ich powierzchni (tab. 1). Charakterystyczne jest, że gminy „parkowe” powiatu wieluńskiego wśród tego typu gmin regionu cechuje jeden z najwyższych odsetków obszaru objętego konserwatorską ochroną przyrody w postaci parku krajobrazowego. W przypadku gminy Konopnica jest to blisko $70 \%$ powierzchni ogółem (rys. 2 ). 
Tabela 1. Udzial powierzchni Sieradzkich Parków Krajobrazowych ${ }^{7}$ w powierzchni gmin w \%

\begin{tabular}{|c|c|}
\hline Nazwa parku krajobrazowego & Gminy z parkiem krajobrazowym \\
\hline Załęczański Park Krajobrazowy & $\begin{array}{c}\text { Pątnów* }(46,9 \%), \text { Wierzchlas* }(36,2 \%) \text {, Działoszyn } \\
(30,2 \%)\end{array}$ \\
\hline $\begin{array}{c}\text { Park Krajobrazowy Międzyrzecza } \\
\text { Warty i Widawki }\end{array}$ & $\begin{array}{l}\text { Konopnica*(67,8\%), Widawa }(54,7 \%) \text {, Burzenin }(36,1 \%) \text {, } \\
\text { Zapolice }(28,4 \%) \text {, Sędziejowice }(11,0 \%) \text {, Sieradz }(9,3 \%) \text {, } \\
\text { Ostrówek* }(1,5 \%) \text {, Rusiec }(1,1 \%) \text { Zduńska Wola }(0,8 \%)\end{array}$ \\
\hline
\end{tabular}

*gminy powiatu wieluńskiego

Źródto: opracowanie własne na podstawie: Bank Danych Lokalnych, GUS 2016.

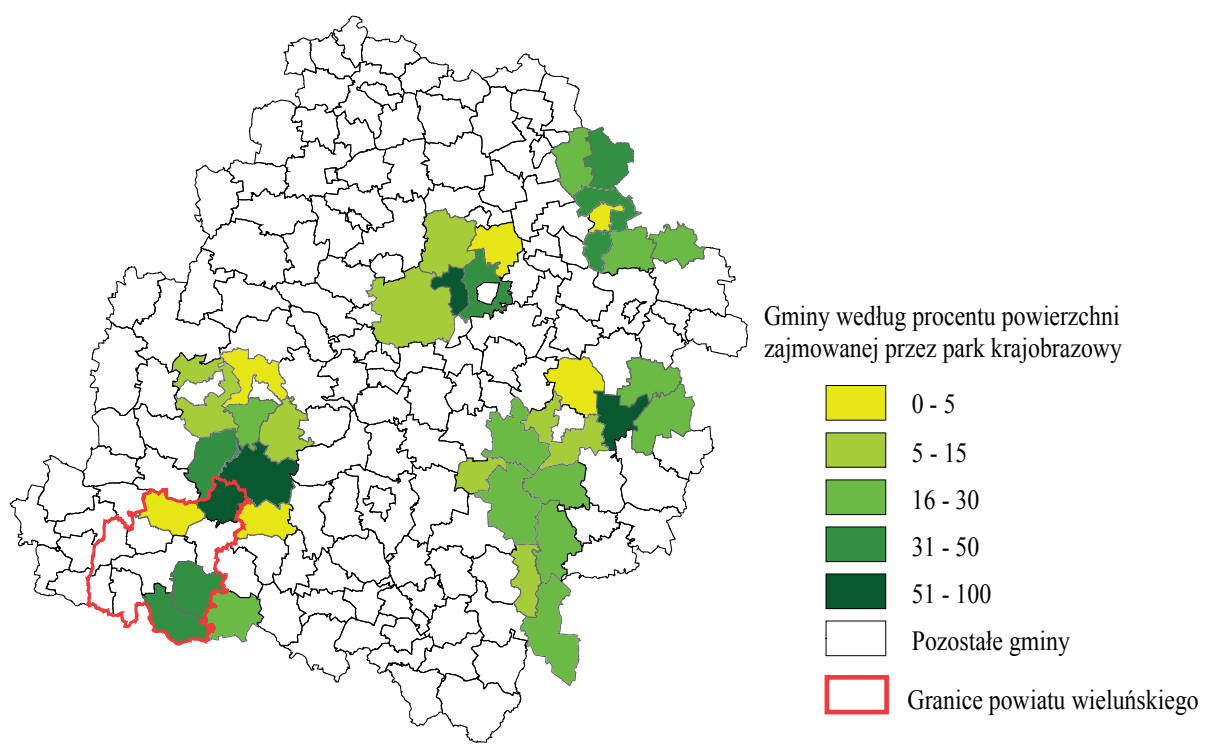

Rysunek 2. Udzial powierzchni parku krajobrazowego w powierzchni ogółem gmin województwa lódzkiego

Źródto: opracowanie własne na podstawie: Bank Danych Lokalnych, GUS 2016.

${ }^{7}$ Sieradzkie Parki Krajobrazowe, swoją nazwę wywodzą od lokalizacji w byłym województwie sieradzkim. Od 1991 r. Załęczański Park Krajobrazowy oraz Park Krajobrazowy Międzyrzecza Warty i Widawki były zarządzane wspólnie przez Dyrekcję Sieradzkich Parków Krajobrazowych. Z dniem 1 stycznia 2013 r. Sieradzkie Parki Krajobrazowe stały się jednym z czterech Oddziałów Terenowych Zespołu Parków Krajobrazowych Województwa Łódzkiego. 
Cechą wyróżniającą ziemie dzisiejszego powiatu wieluńskiego jest położenie na pograniczu krain historycznych, dawnych państw i głównych jednostek administracyjnych Polski w różnych okresach historycznych. Współcześnie peryferyjność obszaru wynikająca z położenia na pograniczu województw, jednocześnie oceniana przez pryzmat korzystnego usytuowania pomiędzy głównymi ośrodkami miejskimi Polski, może być traktowana jako atut i dyskontowana jako czynnik rozwoju. Bogactwo i różnorodność przyrodnicza oraz kulturowa tego obszaru stanowi specyficzny zasób endogeniczny, który jest wartością dla gmin powiatu wieluńskiego i atrakcją turystyczną dla mieszkańców województwa łódzkiego, śląskiego i opolskiego.

\section{Walory przyrodnicze powiatu wieluńskiego}

Walorami środowiska przyrodniczego konkretnego obszaru są wszystkie występujące obiektywnie elementy środowiska przyrodniczego, które podlegają ocenie przez władze jednostek samorządu terytorialnego, potencjalnych inwestorów, mieszkańców czy turystów i stanowią przedmiot ich zainteresowań. W wyniku ich oceny składniki środowiska przyrodniczego stają się elementami subiektywnymi i jako zasoby stanowić mogą o atrakcyjności gospodarczej, kierunkach i tempie rozwoju lokalnego. Odpowiednie wykorzystanie obszarów prawnie chronionych, walorów krajobrazowych, terenów leśnych i zasobów wodnych, właściwości klimatycznych warunkuje budowanie przewag konkurencyjnych nad innymi obszarami, jak również decyduje o specjalizacjach w przestrzeni.

Powiat wieluński geograficznie położony jest na styku Nizin Środkowopolskich i Wyżyn Polskich ${ }^{8}$. Dzięki takiemu usytuowaniu na stosunkowo niewielkiej przestrzeni występuje duża zmienność krajobrazów. Różnorodność form ukształtowania powierzchni pochodzenia akumulacyjnego lub tektonicznego i znaczące deniwelacje sprawiają, że teren powiatu wieluńskiego zdecydowanie wyróżnia się na tle innych powiatów województwa łódzkiego i dominuje jednocześnie nad walorami krajobrazowymi sąsiednich powiatów województw opolskiego i śląskiego, należąc niewątpliwie do najciekawszych krajobrazowo obszarów w środkowej Polsce. Załęczański odcinek rzeki Warty uznawany jest za najbardziej zróżnicowany przyrodniczo w stosunku do całego jej biegu' .

Na terenie powiatu zlokalizowane są dwa parki krajobrazowe: Załęczański i Międzyrzecza Warty i Widawki. Pierwszy z nich położony jest w południowo-zachodniej części województwa łódzkiego na Wyżynie Wieluńskiej i obejmuje najbardziej na północ wysunięte fragmenty Jury Krakowsko-Częstochowskiej.

${ }^{8}$ J. Kondracki, Geografia regionalna Polski, Wydawnictwo Naukowe PWN, Warszawa 2000.

9 J. Mokras-Grabowska, P. Rzeńca (2007), Województwo łódzkie. Przewodnik turystyczny, Regionalna Organizacja Turystyki Województwa Łódzkiego, s. 253. 
O randze parku świadczy fakt, że jest to jeden z czterech pierwszych parków krajobrazowych powołanych w Polsce (5 stycznia 1978 r.). Został utworzony w celu ochrony niepowtarzalnego krajobrazu przełomowej doliny Warty. Teren bogaty jest w zjawiska krasowe - jaskinie, leje, studnie i pola lapiezowe, a także wywierzyska, ponory i okresowo zanikające rzeki. Na wapiennym podłożu spotyka się roślinność wapieniolubną, murawy kserotermiczne i naskalne, w jaskiniach żyje wiele gatunków nietoperzy ${ }^{10}$. Występuje tu również krajobraz polodowcowy z wzgórzami morenowymi i równinami sandrowymi ${ }^{11}$.

Dla ochrony urozmaiconego krajobrazu Kotliny Szczercowskiej, szaty roślinnej unikatowego węzła hydrologicznego rzek Warty, Widawki, Grabi, Niecieczy w 1989 r. utworzony został Park Krajobrazowy Międzyrzecza Warty i Widawki. Ochronie podlegają w nim przełomowe odcinki Warty, z meandrami i starorzeczami, wzgórza kemowe, wydmy i torfowiska. Ze stoków dolin rzecznych rozciągają się rozległe panoramy. W wielu miejscach na powierzchni odsłaniają się utwory wapienne. Doliny rzek urozmaicają liczne urządzenia hydrotechniczne - młyny wodne i inne urządzenia spiętrzające wodę. W miejscach podmokłych i niedostępnych pojawiają się roślinne zespoły bagienne. Niewielkie fragmenty borów bagiennych i grądów związane są najczęściej z podmokłymi dolinami. Bardzo cenne przyrodniczo są murawy i zarośla ciepłolubne ${ }^{12}$.

Najwyższą formą ochrony przyrody w powiecie oprócz parków krajobrazowych są rezerwaty przyrody i obszary Natura 2000. Rezerwaty Hołda (usytuowany na terenie PKMWiW) oraz Lasek Kurowski chronią naturalne zbiorowiska leśne oraz gatunki roślin ściśle chronionych w Polsce. Naturalna meandrująca rzeka i jej dolina zostały docenione i uznane za obszar Natura 2000 - Załęczański Łuk Warty. Obszar ten zajmuje 9312 ha i został wyznaczony na terenie gmin Pątnów i Wierzchlas w powiecie wieluńskim oraz gminy Działoszyn w powiecie pajęczańskim. Obszar charakteryzuje duża różnorodność siedlisk i gatunków cennych związanych z najbardziej na północ wysuniętym fragmentem Jury Polskiej ${ }^{13}$.

Lasy w powiecie wieluńskim zajmują 23031,27 ha, czyli ok. 24,5\% ogólnej powierzchni powiatu. Jest to lesistość wyższa od średniej dla województwa łódzkiego (21,5\%), ale niższa niż dla Polski (29,4\%). Główne kompleksy leśne występują we wschodniej części powiatu w postaci południkowo rozciągniętego pasa, nawiązując głównie do doliny rzeki Warty. Tworzą również wąską i rozczłonkowaną strefę w południowej części województwa łódzkiego. Mając naturalną kontynuację w północnych rejonach powiatów województw opolskiego (oleski) i śląskiego (kłobucki) oraz w powiecie pajęczańskim zaliczane są do rejonu ,zielonych

${ }^{10}$ Raport o stanie środowiska w województwie łódzkim w 2003 r., Biblioteka Monitoringu Środowiska, Łódź 2004, s. 204-210.

${ }^{11}$ Obszary chronione w Polsce, Instytut Ochrony Środowiska, Warszawa 2001, s. 83.

${ }_{12}$ Przyroda województwa sieradzkiego, Urząd Wojewódzki w Sieradzu, Wydawnictwo Terra Sana.

13 www.lodz.rdos.gov.pl, (dostęp: 15.08.2015). 
płuc" Górnego Śląska. Najwyższą lesistość w powiecie wieluńskim obserwuje się w gminach Osjaków (36,3\%), Pątnów $(34,4 \%)$ i Wierzchlas $(37,8 \%)$. Rozległy kompleks leśny wypełnia Załęczański Łuk Warty.

Kompleksowy współczynnik atrakcyjności rekreacyjnej ${ }^{14}$, pozwalający określić atrakcyjność przyrodniczą osiągnął jedną z najwyższych wartości w trzech gminach powiatu wieluńskiego. W czołówce rankingu gmin województwa łódzkiego uplasowały się gminy: Pątnów $(0,87)$, Wierzchlas $(0,81)$ i Konopnica $(0,78)$. Świadczy to o wysokich walorach tego obszaru, wyróżniających się znacząco na tle walorów województwa łódzkiego oraz predyspozycjach tego obszaru dla rozwoju funkcji turystycznej i rekreacyjnej.

\section{Ochrona przestrzeni w gminach powiatu wieluńskiego}

Podstawowymi instrumentami zarządzania obszarowymi formami ochrony przyrody od początki ich powoływania są instrumenty planistyczne polityki przestrzennej. Z założenia instrumenty te mają służyć kształtowaniu ładu przestrzennego oraz przestrzeganiu i propagowaniu zasady ochrony wartości wysoko cenionych. Gmina będąca podstawowym ogniwem planowania przestrzennego ma możliwość kreowania własnej polityki zagospodarowania przestrzeni oraz określania zasad wykorzystania przestrzeni. Tym samym planowanie przestrzenne staje się ważnym obszarem działalności władz samorządowych i odpowiedzialności za stan i jakość przestrzeni gminy, szczególnie w kontekście ochrony krajobrazu w skali lokalnej ${ }^{15}$. Dzięki dostępnym opracowaniom planistycznym tj. studium uwarunkowań i kierunków zagospodarowania przestrzennego oraz miejscowym planom zagospodarowania przestrzennego, gmina może tworzyć spójną wizję polityki przestrzennej będącą odpowiedzią na „oddolną” aktywność inwestycyjną, potrzeby i oczekiwania społeczne oraz wymagania ochrony przyrody. Od postawy władz lokalnych zależy efektywne wykorzystanie tych instrumentów.

${ }^{14}$ Do oceny atrakcyjności przyrodniczej zastosowano metodę bonitacji punktowej. Analizie poddano cztery elementy środowiska geograficznego: topografię terenu, lesistość, wody powierzchniowe i bioklimat, oceniając je w czterostopniowej skali (1-4). Ocena oparta została o współczynnik atrakcyjności, będący stosunkiem liczby uzyskanych punktów do możliwych (w przedziale od 0,0 do 1,0). W badaniach uwzględniono gminy województw: łódzkiego, sieradzkiego i piotrkowskiego w granicach obowiązujących do 1999 r., pomijając tym samym fragmenty PK Wzniesień Łódzkich i Bolimowskiego PK w granicach byłego województwa skierniewickiego. J. Wojciechowska, Walory przyrodnicze regionu łódzkiego (łódzkie, piotrkowskie, sieradzkie), [w:] Studium wiedzy o regionie łódzkim (1995), Łódzkie Towarzystwo Naukowe, Łódź, s. 9-25.

15 Szerzej: A. Rzeńca, Planowanie przestrzenne w gminach województwa łódzkiego. Studium przypadku gmin posiadajacych park krajobrazowy, [w:] N. Ratajczyk, D. Kopeć (red.), Prawo ochrony przyrody a procesy inwestycyjne, Towarzystwo Przyrodników Ziemi Łódzkiej, Łódź 2011. 
Przeprowadzone badania wykazały, iż 7 gmin powiatu wieluńskiego posiada plany miejscowe. Pięć gmin powiatu objęte jest w całości planami, w przypadku dwóch (Wieluń i Wierzchlas) stanowią one niewiele ponad 10\% powierzchni gminy (tab. 2).

Tabela 2. Polityka przestrzenna gmin powiatu wieluńskiego w 2014 roku

\begin{tabular}{|c|c|c|}
\hline Gmina & $\begin{array}{c}\text { Udział terenów objętych } \\
\text { planami miejscowymi (w \%) }\end{array}$ & $\begin{array}{c}\text { Lączna powierzchnia gruntów rolnych, } \\
\text { dla których zmieniono w planach } \\
\text { przeznaczenie na cele nierolnicze (ha) }\end{array}$ \\
\hline Biała & 100 & 240 \\
\hline Czarnożyły & 100 & 483 \\
\hline Konopnica & 100 & 55 \\
\hline Mokrsko & 100 & 55 \\
\hline Osjaków & 100 & 31 \\
\hline Wieluń & 15,0 & - \\
\hline Wierzchlas & 13,2 & 498 \\
\hline
\end{tabular}

Źródto: opracowanie wlasne na podstawie: Bank Danych Lokalnych, GUS 2015, www.stat.gov.pl.

Poprzez plany miejscowe wprowadza się zmiany form użytkowania terenu. Do gmin, które są liderami w tym działaniu należą Czarnożyły i Wierzchlas. W gminie Wierzchlas w przypadku niemal $1 / 3$ powierzchni terenów, dla których sporządzono plan, wprowadzał on zmiany sposobu ich użytkowania. Jednocześnie duża liczba wydawanych decyzji dotyczących budownictwa mieszkaniowego bądź rekreacyjnego świadczy o wysokiej presji inwestycyjnej w tym kierunku (tab. 3, tab. 4.).

Tabela 3. Liczba wydanych decyzji o ustaleniu lokalizacji inwestycji celu publicznego oraz decyzje o ustaleniu warunków zabudowy w gminach powiatu wieluńskiego

\begin{tabular}{|c|c|c|c|c|c|c|c|c|c|c|c|c|}
\hline \multirow{3}{*}{ Gminy } & \multicolumn{4}{|c|}{$\begin{array}{c}\text { Decyzje o ustaleniu lokalizacji } \\
\text { inwestycji celu publicznego }\end{array}$} & \multicolumn{5}{c|}{ Decyzje o warunkach zabudowy } \\
& $\mathbf{2 0 0 9}$ & $\mathbf{2 0 1 0}$ & $\mathbf{2 0 1 1}$ & $\mathbf{2 0 1 2}$ & $\mathbf{2 0 1 3}$ & $\mathbf{2 0 1 4}$ & $\mathbf{2 0 0 9}$ & $\mathbf{2 0 1 0}$ & $\mathbf{2 0 1 1}$ & $\mathbf{2 0 1 2}$ & $\mathbf{2 0 1 3}$ & $\mathbf{2 0 1 4}$ \\
\hline Ostrówek & 2 & 2 & 7 & 3 & 7 & 3 & 47 & 67 & 57 & 47 & 47 & 68 \\
\hline Pątnów & 7 & 4 & 5 & 5 & 6 & - & 97 & 85 & 92 & 81 & 66 & 72 \\
\hline Skomlin & 6 & 4 & 2 & 8 & - & - & 35 & 23 & 23 & 31 & 22 & 27 \\
\hline Wieluń & 25 & 26 & 40 & 17 & 17 & 18 & 218 & 222 & 186 & 135 & 97 & 99 \\
\hline Wierzchlas & 7 & 2 & 5 & 1 & 3 & 3 & 75 & 20 & 15 & 16 & 20 & 14 \\
\hline
\end{tabular}

Źródto: opracowanie własne na podstawie: Bank Danych Lokalnych, GUS 2016, www.stat.gov.pl. 
Wieluń zdecydowanie przoduje w wydawanych decyzjach o ustaleniu warunków zabudowy w zakresie indywidualnych inwestycji budowlanych. Przy rozdrobnieniu planów miejscowych świadczy to o rozwoju suburbanizacji na obszarach wiejskich. Należy zauważyć, że w przypadku gmin wiejskich w czołówce wydawanych decyzji jest gmina Pątnów, która nie ma dotąd planu miejscowego (mimo iż w studium uwarunkowań i kierunków zagospodarowania przestrzennego zaplanowano sporządzenie planu dla całej gminy), a równie atrakcyjna przyrodniczo gmina Wierzchlas w znacznej mierze politykę przestrzenną opiera na decyzjach administracyjnych dysponując planami zaledwie dla $13,2 \%$ powierzchni gminy. Z pespektywy ochrony walorów krajobrazowych powiatu wieluńskiego, będących niezaprzeczalnym potencjałem tego terenu działania takie należy uznać za szczególnie niekorzystne.

Instrumenty planowania przestrzennego mające być „orężem” w ochronie zasobów przyrodniczych i antropogenicznych w gminach powiatu wieluńskiego stosowane są w niedostatecznym zakresie. Po pierwsze, gminy nie wykorzystują miejscowych planów zagospodarowania dla sterowania rozwojem gminy. Po drugie, władze lokalne ulegają presji inwestycyjnej, bazując na decyzjach o warunkach zabudowy i zagospodarowaniu terenu (tab. 4). Podejmowane bieżące decyzje planistyczne obarczone są ryzykiem i negatywnymi konsekwencjami zarówno w bliskiej jak i dalszej przyszłości, i w efekcie mogą stać się źródłem konfliktów przestrzennych.

Tabela 4. Wydane decyzje dotyczące zabudowy mieszkaniowej jednorodzinnej w gminach powiatu wieluńskiego

\begin{tabular}{|c|c|c|c|c|c|c|}
\hline \multirow{2}{*}{ Gminy } & \multicolumn{5}{|c|}{ Decyzje dotyczące zabudowy mieszkaniowej jednorodzinnej } \\
\cline { 2 - 7 } & $\mathbf{2 0 0 9}$ & $\mathbf{2 0 1 0}$ & $\mathbf{2 0 1 1}$ & $\mathbf{2 0 1 2}$ & $\mathbf{2 0 1 3}$ & $\mathbf{2 0 1 4}$ \\
\hline Ostrówek & 41 & 57 & 55 & 46 & 46 & 52 \\
\hline Pątnów & 89 & 62 & 62 & 48 & 46 & 43 \\
\hline Skomlin & 22 & 13 & 20 & 13 & 14 & 17 \\
\hline Wieluń & 124 & 152 & 143 & 74 & 57 & 56 \\
\hline Wierzchlas & 45 & 12 & 12 & 12 & 12 & 11 \\
\hline
\end{tabular}

Źródto: opracowanie własne na podstawie: Bank Danych Lokalnych, GUS 2016, www.stat.gov.pl. 


\section{Infrastruktura ochrony środowiska}

Wiodącym zadaniem własnym wszystkich gmin są sprawy ochrony środowiska. Aktywna polityka ekologiczna na poziomie lokalnym koncentruje się przede wszystkim na inwestycjach infrastrukturalnych, stymulowaniu proekologicznych zachowań użytkowników środowiska oraz wdrażaniu proekologicznych rozwiązań w obiektach użyteczności publicznej. W realizacji zadań ochrony środowiska kluczowe jest zachowanie istniejącego stanu ekosystemów i dążenie do poprawy jakości środowiska poprzez wyeliminowanie lub przynajmniej ograniczenie szkodliwych oddziaływań ze strony lokalnych społeczności.

Powiat wieluński należy do jednostek o najniższym poborze i zużyciu wody zarówno na potrzeby gospodarcze jak i ludności (zużycie roczne - $3325 \mathrm{dam}^{3}$ ). Dominuje zużycie wody na potrzeby gospodarstw domowych, które oscyluje wokół poziomu 2332 dam $^{3}$ (stan 2014 r.) Zużycie wody na 1 mieszkańca w powiecie jest stabilne, wynosi $42,9 \mathrm{~m}^{3}$ i jest to wartość zdecydowanie niższa niż w regionie łódzkim $\left(104,4 \mathrm{~m}^{3}\right)$ i w kraju $\left(266,2 \mathrm{~m}^{3}\right)$. Infrastruktura wodociągowa w powiecie jest bardzo dobrze rozwinięta. Powiat wieluński jest w czołówce powiatów regionu łódzkiego jeśli chodzi o dostępność sieci wodociągowej (obejmuje 95,2\% ludności), jedynie dwie gminy: Biała i Ostrówek są mniej uprzywilejowane (nieco ponad 80\% ludności korzysta z sieci wodociągowej).

Przyrost w latach 2005-2014 ogólnej długości sieci kanalizacyjnej o ponad $100 \%$ jest pozytywnym wskaźnikiem poprawy warunków życia mieszkańców. Niepokojące są natomiast duże dysproporcje pomiędzy poszczególnymi gminami, przy czym wyraźnie zaznacza się podział powiatu wieluńskiego na stosunkowo słabo wyposażoną część wschodnią i uprzywilejowane pod tym względem tereny w części zachodniej i środkowej (tab. 5). Jednym z czynników warunkujących takie właściwości rozwoju sieci kanalizacyjnej jest zróżnicowanie typów morfologicznych wsi w poszczególnych strefach powiatu. W gminach zachodniej i środkowej jego części występują głównie wsie o zwartej zabudowie i liniowym rozciągnięciu, natomiast $\mathrm{w}$ gminach na wschodzie dominują wsie o zabudowie bardziej rozproszonej, gdzie budowa dłuższych odcinków sieci kanalizacyjnej jest ekonomicznie nieuzasadniona. Uzupełnienie sieci kanalizacji ściekowej w powiecie stanowią przydomowe oczyszczalnie ścieków, które są alternatywą w przypadku zabudowy rozproszonej. W ostatnich 5 latach ich liczba wyraźnie wzrosła. Zdecydowane zmiany nastąpiły w gminach: Konopnica, Ostrówek, Mokrsko, Pątnów. Szczególnie istotne jest, iż zmiany te nastąpiły w gminie Pątnów, w której nie ma sieci kanalizacyjnej (tab. 6). 
Tabela 5. Udział korzystających z sieci kanalizacyjnej w latach: 2002, 2010, 2014 (w \%)

\begin{tabular}{|l|c|c|c|}
\hline Jednostka administracyjna & $\mathbf{2 0 0 2}$ & $\mathbf{2 0 1 0}$ & $\mathbf{2 0 1 4}$ \\
\hline Powiat wieluński & 32,2 & 41,0 & 45,5 \\
\hline Biała & - & 0,9 & 0,9 \\
\hline Czarnożyły & - & 44,5 & 67,7 \\
\hline Konopnica & 7,8 & 15,5 & 19,7 \\
\hline Mokrsko & 4,3 & 21,0 & 29,9 \\
\hline Osjaków & 9,9 & 23,2 & 27,8 \\
\hline Ostrówek & 6,3 & 8,8 & 10,0 \\
\hline Pątnów & 0,0 & - & - \\
\hline Skomlin & 2,2 & 34,5 & 42,8 \\
\hline Wieluń & 72,5 & 77,9 & 81,2 \\
\hline Wieluń - miasto & 88,9 & 90,6 & 91,8 \\
\hline Wieluń - obszar wiejski & 25,1 & 42,8 & 53,4 \\
\hline Wierzchlas & - & - & 5,6 \\
\hline
\end{tabular}

Źródto: opracowanie własne na podstawie: Bank Danych Lokalnych, GUS 2016, www.stat.gov.pl.

Tabela 6. Liczba przydomowych oczyszczalni ścieków w gminach Powiatu Wieluńskiego w latach: 2002, 2010, 2014

\begin{tabular}{|l|c|c|c|}
\hline Jednostka administracyjna & $\mathbf{2 0 0 9}$ & $\mathbf{2 0 1 0}$ & $\mathbf{2 0 1 4}$ \\
\hline Powiat wieluński & 98 & 336 & 1127 \\
\hline Biała & 12 & 18 & 168 \\
\hline Czarnożyły & - & 3 & 11 \\
\hline Konopnica & 10 & 10 & 135 \\
\hline Mokrsko & 4 & 7 & 115 \\
\hline Osjaków & 22 & 28 & 135 \\
\hline Ostrówek & 4 & 5 & 274 \\
\hline Pątnów & 13 & 164 & 178 \\
\hline Skomlin & - & - & 2 \\
\hline Wieluń & 17 & 17 & 25 \\
\hline Wieluń - miasto & 7 & 7 & 11 \\
\hline Wieluń - obszar wiejski & 10 & 10 & 14 \\
\hline Wierzchlas & 16 & 84 & 84 \\
\hline
\end{tabular}

Źródło: opracowanie własne na podstawie: Bank Danych Lokalnych, GUS 2016, www.stat.gov.pl. 
W 2014 r. na obszarach wiejskich powiatu wieluńskiego z sieci kanalizacyjnej korzystało 45,5\% ogółu ludności. Zważywszy na fakt, że powiat ma charakter rolniczym identyfikowane zmiany należy ocenić pozytywnie, bowiem wskaźnik ten jest wyższy niż w województwie łódzkim (22,5\%) oraz w kraju (37,3\%). Rozbudowa sieci kanalizacyjnej spowodowała, iż odsetek ludności korzystającej z oczyszczalni ścieków w ostatnich latach znacznie wzrósł, choć nie wszystkie gminy w powiecie posiadają oczyszczalnie ścieków. Diametralna poprawa sytuacji nastąpiła w przypadku gmin: Czarnożyły, Wieluń i Skomlin.

Generalnie, mimo dostrzegalnej poprawy, wyposażenie gmin w infrastrukturę gospodarki ściekowej nadal jest niewystarczające. W wielu gminach wciąż obserwujemy braki w infrastrukturze i dysproporcje pomiędzy długością sieci wodociągowej a kanalizacyjnej. W części gmin (Konopnica, Ostrówek, Osjaków, Mokrsko) widoczne są działania władz zmierzające do kompleksowego uregulowania kwestii gospodarki wodno-ściekowej poprzez rozwój i różnicowanie infrastruktury w tym zakresie (sieć kanalizacyjna oraz przydomowe oczyszczalnie ścieków).

Równie newralgiczną kwestią dla gmin jest poprawa działań w zakresie gospodarki odpadami. Powiat wieluński należy do grupy powiatów o niskiej wartości zebranych odpadów zmieszanych, niepokojący jest jednak stały wzrost ich ilości, głównie z gospodarstw domowych. Pomimo faktu, że roczna ilość odpadów na mieszkańca w powiecie jest niższa niż wartość zakładana w Krajowym Planie Gospodarki Odpadami, w niektórych gminach wartość wzrosła niemal o 100\% w przeciągu dwóch lat (Biała, Mokrsko, Wieluń, Wierzchlas) (tab. 7).

Tabela 7. Produkcja odpadów przez mieszkańców w powiecie wieluńskim według gmin

\begin{tabular}{|l|c|c|c|c|}
\hline \multirow{2}{*}{\begin{tabular}{c}
\multirow{2}{*}{$\begin{array}{c}\text { Jednostka } \\
\text { administracyjna }\end{array}$} \\
\cline { 2 - 5 }
\end{tabular}} & \multicolumn{2}{c|}{$\begin{array}{c}\text { Zebrane odpady } \\
\text { zmieszane ogólem (t) }\end{array}$} & \multicolumn{2}{c|}{$\begin{array}{c}\text { Odpady z gospodarstw domowych } \\
\text { przypadające na 1 mieszkańca (kg) }\end{array}$} \\
\cline { 2 - 5 } & $\mathbf{2 0 0 9}$ & $\mathbf{2 0 1 4}$ & $\mathbf{2 0 0 9}$ & $\mathbf{2 0 1 4}$ \\
\hline Powiat wieluński & 6342,59 & 8021,16 & 53,4 & 130,8 \\
\hline Biała & 152,94 & 511,76 & 16,5 & 117,1 \\
\hline Czarnożyły & 247,50 & 427,23 & 40,1 & 113,8 \\
\hline Konopnica & 328,51 & 275,34 & 38,3 & 92,0 \\
\hline Mokrsko & 215,88 & 411,66 & 28,6 & 97,3 \\
\hline Osjaków & 349,94 & 439,38 & 56,9 & 132,4 \\
\hline Ostrówek & 237,20 & 349,38 & 34,2 & 96,2 \\
\hline Pątnów & 310,21 & 392,13 & 32,1 & 74,3 \\
\hline Skomlin & 78,20 & 367,24 & 12,8 & 130,0 \\
\hline Wieluń & 4085,19 & 4363,10 & 81,3 & 172,5 \\
\hline Wieluń - miasto & 3457,76 & 3699,00 & 86,2 & 206,3 \\
\hline Wieluń - obszar wiejski & 627,43 & 664,10 & 67,7 & 83,0 \\
\hline Wierzchlas & 337,02 & 483,84 & 37,3 & 78,2 \\
\hline
\end{tabular}


Wartym odnotowania są podejmowane działania władz lokalnych w kwestii likwidacji dzikich wysypisk śmieci. Z 10 zidentyfikowanych w 2012 r. nielegalnych wysypisk, zostały jedynie 2 . Sam fakt występowania dzikich wysypisk i nawracający problem ich usuwania świadczy jednak o niskiej świadomości ekologicznej mieszkańców.

Problemem trudno identyfikowanych zagrożeń dla jakości środowiska i warunków życia ludności są zanieczyszczenia powietrza pochodzące z lokalnych źródeł. Emisja przypowierzchniowa, pochodząca z niskich emitorów, odprowadzających gazowe i pyłowe produkty spalania z domowych palenisk i lokalnych kotłowni węglowych, szczególnie w sezonie grzewczym stanowi istotny problem dla wszystkich gmin. W warunkach braku możliwości rozwoju sieci ciepłowniczej i gazowej istotna jest promocja i wsparcie w zakresie proekologicznych rozwiązań termomodernizacyjnych i technik grzewczych (instalacje solarne, pompy ciepła).

Problematyczna jest energetyka wiatrowa, która na terenie gmin powiatu wieluńskiego ma dogodne warunki rozwoju, wynikające $\mathrm{z}$ wielkości przeciętnych prędkości wiatru w tej części Polski, charakteru ukształtowania powierzchni i braku wyraźnych przeszkód terenowych, zakłócających swobodny przepływ powietrza. O popularności energetyki wiatrowej i potencjale w tym zakresie świadczą powstałe elektrownie i plany lokalizacji kolejnych turbin wiatrowych w 5 gminach (tab. 8). W warunkach oporu społecznego w stosunku do dużych inwestycji energetycznych, szczególnie farm wiatrowych ${ }^{16}$, oraz wysokich walorów krajobrazowych gminy powinny przeanalizować powyższe plany i zaniechać tego typu inwestycji lub zmienić ich lokalizację.

Tabela 8. Czynne i planowane elektrownie wiatrowe w gminach Powiatu Wieluńskiego

\begin{tabular}{|l|l|l|}
\hline \multicolumn{1}{|c|}{ Gmina } & $\begin{array}{l}\text { Czynne elektrownie wiatrowe } \\
\text { Liczba turbin wiatrowych }\end{array}$ & \multicolumn{1}{c|}{ Planowane elektrownie wiatrowe } \\
\hline Biała & 2 (Lysonia), 1 (Naramice) & $\begin{array}{l}\text { Planowana budowa 25-28 turbin wiatrowych } \\
\text { w południowej części gminy }\end{array}$ \\
\hline Czarnożyły & $\begin{array}{l}4 \text { (Staw), 2 (Stawek), 2 (Raczyn), } \\
3 \text { (Czarnożyły) }\end{array}$ & $\begin{array}{l}\text { Wniosek o wydanie decyzji o środowiskowych } \\
\text { uwarunkowaniach dla 14 turbin wiatrowych }\end{array}$ \\
\hline Osjaków & $\begin{array}{l}1 \text { (Drobnice), 1 (Osjaków, w bu- } \\
\text { dowie) }\end{array}$ & $\begin{array}{l}\text { Planowane inwestycje, ale brak zgodności z pla- } \\
\text { nem miejscowym }\end{array}$ \\
\hline Ostrówek & 1 (Namierzyn) & $\begin{array}{l}\text { Wydane 3 decyzje środowiskowe, złożono } \\
\text { kolejne 9 wniosków o wydania decyzji środowi- } \\
\text { skowej, postępowanie w toku }\end{array}$ \\
\hline Pątnów & $\begin{array}{l}2 \text { (Kamionka), 5 (Pątnów), } \\
1 \text { (Dzietrzniki), 2 (Popowice) }\end{array}$ & \multicolumn{2}{|l}{-} \\
\hline
\end{tabular}

${ }^{16}$ Przeprowadzone w gminie Mokrsko w czerwcu 2013 r. ok. 80\% głosujących wyraziło sprzeciw budowie farmy wiatrowej. 


\begin{tabular}{|l|l|c|}
\hline \multicolumn{1}{|c|}{ Gmina } & $\begin{array}{c}\text { Czynne elektrownie wiatrowe } \\
\text { Liczba turbin wiatrowych }\end{array}$ & \multicolumn{1}{c|}{ Planowane elektrownie wiatrowe } \\
\hline Skomlin & 1 (Skomlin) & - \\
\hline Wieluń & 1 (Olewin), 1 (Turów) & - \\
\hline Wierzchlas & 1 (Mierzyce) & $\begin{array}{l}\text { Złożono 21 wniosków o wydanie decyzji o śro- } \\
\text { dowiskowych uwarunkowaniach, ale postępo- } \\
\text { wanie zawieszono }\end{array}$ \\
\hline
\end{tabular}

Źródto: opracowanie własne na podstawie danych z urzędów gmin, stan grudzień 2013.

\section{Podsumowanie i wnioski}

Wyzwaniem dla gmin o wysokich walorach przyrodniczych jest wdrażanie takich rozwiązań, które pozwolą na kompleksową ochronę środowiska przyrodniczego poprzez utrzymanie różnorodności w strukturze przestrzennej, systematyczną poprawę jakości środowiska oraz wielofunkcyjny rozwój obszaru bez naruszania równowagi w środowisku. Jak zauważył Romuald Olaczek, obecnie, gdy prymat interesu prywatnego góruje nad dobrem publicznym ${ }^{17}$, trudniej jest niż dawniej chronić przyrodę i jej wartości ${ }^{18}$. Potwierdzenie tego poglądu znajdujemy w praktyce planistycznej. Zdaniem Jana Paryska źle pojęta samorządność, wolność i demokracja może doprowadzić do bezwzględnego uznawania pierwszeństwa prawa własności i swobody dysponowania terenem. W efekcie zagospodarowanie przestrzeni jest podporządkowane partykularnym interesom i zaprzeczeniem idei kształtowania ładu przestrzennego, a tym samym prowadzi do degradacji przestrzeni ${ }^{19}$. Jednocześnie osłabienie rangi planowania przestrzennego nie sprzyja skuteczności zrównoważonego i trwałego gospodarowania na obszarach chronionych. W polityce przestrzennej gmin powiatu wieluńskiego, park krajobrazowy nie jest wystarczającym czynnikiem motywującym do uregulowania kwestii zagospodarowania przestrzeni. Jedynie gmina Konopnica posiada plan miejscowy dla całego obszaru. Na przeciwległym biegunie znajduje się gmina Pątnów, która politykę przestrzenną opiera wyłącznie

17 Utworzenie parku narodowego czy rezerwatu przyrody na gruntach prywatnych może nastąpić za zgodą właściciela lub w przypadku braku zgody w trybie wywłaszczenia za odszkodowaniem - Ustawa o ochronie przyrody z 2004 r., art. 7, ust. 2.

${ }^{18}$ R. Olaczek, Parki krajobrazowe w systemie ochrony przyrody w Polsce, [w:] J.K. Kurowski, P. Witosławski, Funkcjonowanie parków krajobrazowych w Polsce, Wydawnictwo Uniwersytetu Łódzkiego, Łódź 2002, s. 7.

19 J.J. Parysek, Wybrane problemy teoretyczno-metodologiczne gospodarki przestrzennej, [w:] Parysek J.J. (red.), Rozwój lokalny: zagospodarowanie przestrzenne i nisze atrakcyjności gospodarczej, PAN KPZK, Studia, t. CIV, PWN, Warszawa 1995, s. 29. 
na decyzjach administracyjnych, ich coroczna wysoka liczba świadczy o dużej presji urbanizacyjnej na terenach cennych przyrodniczo.

Mimo, że władze lokalne koncentrują się na likwidacji zapóźnień i dysproporcji w wyposażeniu gminy w infrastrukturę ochrony środowiska, nadal niezbędne jest uregulowanie kwestii gospodarki ściekowej, dopasowanie rozwiązań w zakresie infrastruktury wodno-kanalizacyjnej do lokalnych warunków i charakteru zabudowy mieszkaniowej oraz dynamiki i charakteru zmian zagospodarowania przestrzeni. Szczególnej uwagi we wszystkich gminach wymaga problem wzrastającej liczby odpadów oraz niski stopień ich segregacji. Utrzymanie negatywnych trendów w niedalekiej przyszłości będzie miało konsekwencje nie tylko dla jakości środowiska, ale również dla budżetów gospodarstw domowych jak i budżetów gmin (egzekucja opłat, likwidacja dzikich wysypisk etc.). Zdecydowanych działań wymaga ograniczanie zanieczyszczeń powietrza z palenisk indywidualnych. Dostępne formy pomocy finansowej (głównie z WFOŚiGW) oraz procedury ich przyznawania powinny faworyzować gospodarstwa domowe oraz instytucje publiczne zlokalizowane na obszarach chronionych.

Dla skutecznej ochrony środowiska konieczne jest współdziałanie międzygminne w kontekście rozwoju gospodarki niskoemisyjnej, kompleksowej ochrony krajobrazu oraz stymulowania procesów rozwoju. Terytorialne podejście do rozwoju daje możliwość kompleksowego spojrzenia na procesy zarządzania ochroną środowiska oraz projektowania polityki rozwoju w oparciu o walory środowiska przyrodniczego. Istotne znaczenie dla całego powiatu będzie miało planowanie zintegrowane, które pozwoli na koncentrację aktywności wokół kluczowych, przyrodniczych atutów powiatu ${ }^{20}$. Pożądane są zatem projekty zintegrowane, wieloelementowe i wielopodmiotowe, mobilizujące władze lokalne do intensyfikacji działań na rzecz ochrony środowiska oraz budowania oferty powiatu w oparciu o jego potencjał. O słuszności tej drogi rozwoju, w oparciu o potencjał przyrodniczy, świadczy doroczny ranking gmin, w którym w czołówce gmin znalazły się gminy turystyczne będące znanymi kurortami, jak i te mniej znane (tab. 9). W dobie turystyki masowej coraz częściej wybierane są małe ośrodki o turystyce niszowej, które opierają swój rozwój na specyficznych, indywidualnych zasobach przyrodniczych.

${ }^{20}$ Szerzej o nowej filozofii zintegrowanego planowania rozwoju pisze: A. Nowakowska, Zintegrowane plany rozwoju - w stronę terytorialno-funkcjonalnego podejścia do rozwoju jednostki terytorialnej, [w:] A. Nowakowska (red.), Nowoczesne metody i narzędzia zarzadzania rozwojem lokalnym i regionalnym, Wydawnictwo Uniwersytetu Łódzkiego, Łódź 2015; A. Rzeńca, Kapitat przyrodniczy w planowaniu zintegrowanym, [w:] B. Banachowicz, K. Wojtaszczyk, M. Żak-Skwierczyńska (red.), Problemy zarzadzania w jednostkach samorzadu terytorialnego, Uniwersytet Łódzki, Łódź 2015; Z. Przygodzki, Kapitat terytorialny w zintegrowanym planowaniu rozwoju. Koncepcje wspótpracy, Barometr Regionalny. Analizy i prognozy, Tom 13, $2015, \mathrm{nr} 4$. 
Tabela 9. Gminy o najwyższej pozycji w rankingu gmin miejskich i miejsko-wiejskich w Polsce

\begin{tabular}{|l|l|}
\hline $\begin{array}{l}\text { Gminy miejskie } \\
\text { i miejsko-wiejskie }\end{array}$ & $\begin{array}{l}\text { Dziwnów, Krynica Morska, Kalisz Pomorski, Karpacz, Babimost, Nowe } \\
\text { Warpno, Świeradów Zdrój, Karlino, Tolkmicko, Mszczonów, Szklarska } \\
\text { Poręba }\end{array}$ \\
\hline Gminy wiejskie & $\begin{array}{l}\text { Rząśnia, Ożarowice, Narewka, Mielno, Postomino, Kleszczów, Sulmierzy- } \\
\text { ce, Jerzmanowa, Pszczew, Mielnik }\end{array}$ \\
\hline
\end{tabular}

* Kryteria: dochody własne, nakłady inwestycyjne w przeliczeniu na 1 mieszkańca, zadłużenie, pozyskanie środków unijnych.

Źródlo: opracowanie własne na podstawie: Tygodnik Wprost 32/2015.

W najbliższym czasie sytuacja w powiecie wieluńskim może ulec diametralnej zmianie, a kluczowe znaczenie dla kondycji środowiska przyrodniczego i ochrony walorów przyrodniczych będzie miała decyzja o uruchomieniu odkrywkowej kopalni węgla brunatnego w rejonie Złoczewa. Obecnie trwają prace wstępne. W przypadku jej uruchomienia gminy północnej części powiatu wieluńskiego znajdą się w strefie funkcjonalnej ,Zagłębie Górniczo-Energetyczne BełchatówSzczerców-Złoczew" i w zasięgu jego bezpośredniego jaki i pośredniego oddziaływania. Inwestycja ta przyczyni się do zaburzenia stosunków hydrologicznych, które mogą radykalnie zmienić sytuację w zakresie zasobności i jakości wód oraz doprowadzić do zmiany siedlisk przyrodniczych, obniżenia jakości gleb, obniżenia wartości i produktywności użytków rolnych w jej otoczeniu. Tym samym wymusi nowy zakres działań władz lokalnych.

\section{Bibliografia}

Barca F., An Agenda for a Reformed Cohesion Policy. A place-based ap $\neg$ proach to meeting European Union challenges and expectations, Independent Report prepared at the request of Danuta Hübner, Commissioner for Regional Policy, 2009, http://ec.europa.eu/regional_policy/archive/policy/future/pdf/report_barca_v0306.pdf.

Costanza R. et al., The value of the world's ecosystem services and natural capital, Nature 1997, $387(6630)$.

Kondracki J., Geografia regionalna Polski, PWN, Warszawa 2000.

Mokras-Grabowska J., Rzeńca P., Województwo łódzkie. Przewodnik turystyczny, Regionalna Organizacja Turystyki Województwa Łódzkiego, Łódź 2007.

Obszary chronione w Polsce, Instytut Ochrony Środowiska, Warszawa 2001.

Olaczek R., Parki krajobrazowe w systemie ochrony przyrody w Polsce, [w:] J.K. Kurowski, P. Witosławski, Funkcjonowanie parków krajobrazowych w Polsce, Wydawnictwo Uniwersytetu Łódzkiego, Łódź 2002.

Parysek J.J., Wybrane problemy teoretyczno-metodologiczne gospodarki przestrzennej, [w:] Parysek J.J. (red.), Rozwój lokalny: zagospodarowanie przestrzenne i nisze atrakcyjności gospodarczej, PAN KPZK, Studia, t. CIV, PWN, Warszawa 1995. 
Przyroda województwa sieradzkiego, praca zbiorowa, Urząd Wojewódzki w Sieradzu, Wydawnictwo Terra Sana.

Raport o stanie środowiska w województwie tódzkim w 2003 r., Biblioteka Monitoringu Środowiska, Łódź 2004.

Rzeńca A., Planowanie przestrzenne w gminach województwa łódzkiego. Studium przypadku gmin posiadajacych park krajobrazowy, [w:] N. Ratajczyk, D. Kopeć (red.), Prawo ochrony przyrody a procesy inwestycyjne, Towarzystwo Przyrodników Ziemi Łódzkiej, Łódź 2011.

Wojciechowska J., Walory przyrodnicze regionu łódzkiego (łódzkie, piotrkowskie, sieradzkie), [w:] Studium wiedzy o regionie łódzkim, praca zbiorowa, Łódzkie Towarzystwo Naukowe, Łódź 1995.

www.lodz.rdos.gov.pl

http://www.stat.gov.pl/vademecum/vademecum_lodzkie/portrety_powiatow/powiat_WIELUNSKI.pdf.

\section{Streszczenie}

W warunkach dynamicznych procesów społeczno-gospodarczych wyzwaniem dla jednostek terytorialnych (gmin) jest ochrona przestrzeni cennej przyrodniczo. Bogactwo i różnorodność środowiska przyrodniczego oraz kulturowego terytorium stanowi specyficzny zasób endogeniczny, który jest wartością, ale wymaga intensyfikacji działań na rzecz ich ochrony.

Przedmiotem artykułu jest problematyka ochrony środowiska, podmiotem badań - gminy powiatu wieluńskiego o wybitnych walorach przyrodniczych będące atrakcją turystyczną dla mieszkańców województwa łódzkiego, śląskiego i opolskiego. W artykule przedstawiono główne obszary aktywności władz lokalnych w zakresie ochrony środowiska oraz dokonano identyfikacji głównych problemów. Szczególną uwagę zwrócono na gminy, na których terenie znajduje się park krajobrazowy.

Słowa kluczowe: gmina, walory przyrodnicze, park krajobrazowy, ochrona środowiska

Numer klasyfikacji JEL: Q58, Q56 